\title{
Bioprospecting of endophytic bacteria from the Indian Himalayas and their role in plant growth promotion of maize (Zea mays L.)
}

\author{
Kusam Lata Rana ${ }^{1}$, Divjot Kour ${ }^{1}$, Tanvir Kaur ${ }^{1}$, Rubee Devi ${ }^{1}$, Ashok Yadav², Ajar Nath Yadav ${ }^{1 *}$ \\ ${ }^{1}$ Department of Biotechnology, Dr. Khem Singh Gill Akal College of Agriculture, Eternal University, Baru Sahib, India \\ ${ }^{2}$ Department of Botany, Institute of Science, Banaras Hindu University, Varanasi, India
}

\begin{tabular}{l}
\hline ARTICLE INFO \\
\hline Article history: \\
Received on: October 18, 2020 \\
Accepted on: November 24, 2020 \\
Available online: May 10, 2021 \\
\hline
\end{tabular}

Key words:

Biochemical levels, endophytes, maize, Pantoea, plant growth promotion.

\begin{abstract}
Endophytes are the hidden companions of inner plant tissues with the ability to undergo various plant growth mechanisms to benefit their host. Looking at the endophytic microbes' benefits, a total of 67 putative endophytic bacteria were isolated using different nutrient growth media from three diverse maize genotypes grown at Baru Sahib the "Valley of Divine Peace" Himachal Pradesh. Out of the 67, 10 endophytic bacterial isolates were selected for further characterization on the basis of plant growth-promoting (PGP) attributes. Phosphorus (P) and potassium $(\mathrm{K})$ solubilization was observed in about $25 \%$ of the bacterial isolates. Additionally, bacterial endophytes' ability to undergo mechanisms like nitrogenase activity, production of indole acetic acids, and siderophores was also studied. Among the 10 selected bacterial strains, three efficient endophytic PGP strains EU-A2SK1, EU-M4ARAct, and EU-E1RT3-1 were identified as Pseudomonas brenneri, Ewingella americana, and Pantoea agglomerans, respectively. The phylogenetic tree was constructed to know the taxonomical affiliations of selected bacterial strains. These three efficient endophytic bacterial strains were tested on the maize seeds. The isolates efficiently increased the shoot length and enhanced anthocyanin, chlorophyll content, physiological available iron, and total protein content when compared to untreated control maize plants at 60 days of maize plant growth. These bacterial strains, as single or in a consortium, could be useful as bioinoculants for sustainable agriculture.
\end{abstract}

\section{INTRODUCTION}

Staple food is required to meet the increasing demands of the rising world population. In 2020, the global demand for maize was estimated to increase by $45 \%$ when compared to wheat and rice. Following wheat and rice, maize was ranked as the third important cereal crop in the world [1]. Maize mostly supplies with $365 \mathrm{Kcal} / 100 \mathrm{~g}$ of energy as compared to wheat and rice. It is one of the major components with various applications in food, feed, and industrial areas [2]. Maize requires an adequate supply of chemical fertilizers for maintaining proper growth and high yield. Phosphorus is one of the important macronutrients required for maintaining the physiological processes in early and later stages of maize development [3]. The deficiency of phosphorus fertilizers

\footnotetext{
*Corresponding Author

Ajar Nath Yadav, Department of Biotechnology, Dr. Khem Singh Gill Akal College of Agriculture, Eternal University, Baru Sahib, India. Email: ajarbiotech@gmail.com ; ajar@eternaluniversity.edu.in Contributed equally to the present work
}

particularly during early developmental stages resulted in the reduced growth of the root system and uptake of nutrients which negatively impacted the growth and development of maize for the rest of the season. Over the last few centuries, farmers have been greatly encouraged to increase the applications of phosphorus fertilizers for better yields without the fear of drawbacks of increased phosphorus accumulation in soil and surface runoff [4]. In the future, excessive utilization of phosphorus fertilizers will lead to harmful impacts on the environment, as well as human health. The low solubility of phosphate in the soil leads to easily runoff in lakes, rivers, and oceans and further causes degradation of water quality and eutrophication [5].

The alternative approach to chemical fertilizers is the use of biofertilizers. Biofertilizers mainly consist of living cells of selected microbes which utilize different mechanisms such as those providing nutrients through the root system, improving plant fitness and fertility of soil to improve crop yield, and also play a vital role in nutrient cycling. Plant roots are the hotspots for the microbes due to the availability of root exudates and rhizodeposits 
as source of nutrients for microbes [6]. The rhizospheric region is a host for plant growth-promoting (PGP) microbes, although the literature had reported that the interior of plant organs, such as root, stem, leaves, flowers, seeds, and fruits, to be mostly populated by endophytic microbes generally derived from the rhizospheric regions [7]. Endophytic microbes live inside the tissue of plants without causing any harmful impact on the health of host plant and enhance the growth of plant through direct and indirect mechanisms [8]. The direct mechanisms consist of biological nitrogen fixation, helping plants in acquisition of different nutrients, and synthesis of phytohormones auxin (Indole-3-acetic-acid), cytokinins, gibberellins, and ethylene [9]. The indirect mechanisms consist of prevention of harmful effect of phytopathogenic microbes, production of siderophores, and ammonia [10].

In India, about $98 \%$ of the soil has been reported to face the deficiency of the phosphorus nutrient. The content of $\mathrm{P}$ is about $0.05 \%(w / w)$ in average soil, but a very low amount $0.1 \%$ of the total $\mathrm{P}$ is available to plants due to poor solubility. The phosphorussolubilizing bacteria, also referred to as phosphobacteria, mostly secrete low molecular weight organic acids (fumaric acid, succinic acid, acetic acid, gluconic acid, lactic acid) or extracellular enzymes, which decrease the $\mathrm{pH}$ and solubilize the mineral phosphates [11]. A vast diversity of PGP- endophytic bacteria belonging to different genera Acidovorax, Agrobacterium, Bacillus, Burkholderia, Curtobacterium, Enterobacter, Pantoea, Pseudomonas, Rhanella, Klebsiella, and Variovorax from maize have been reported [11-15].

The effective PGP microbes isolated from one specific area may show positive output, whereas, with the changes in climatic condition, soil type, and availability of different components in the soil, the similar PGP microbes may not be able to perform their activity the same way [16]. The objective of the present study was to isolate and characterize phosphorus-solubilizing activity and other attributes of plant growth promotion of endophytic bacteria from maize growing at Baru Sahib, located in Himachal Pradesh, Northern Hill Zone, in India. Furthermore, there is no data available on phosphorus-solubilizing endophytic bacteria from this region. We further aimed to assess the advancement in phylogenetic diversity of bacterial endophytes and finally selected the PGP endophytic bacteria with potential application to be used as bioinoculants under in-vitro conditions.

\section{MATERIALS AND METHODS}

\subsection{Isolation and Enumeration of Bacterial Endophytes}

Healthy genotypes of maize as local red, local white, and anthocyanin rich were collected from different fields of Baru Sahib, Sirmaur, Himachal Pradesh, India, for the isolation and enumeration of endophytic bacteria. Baru Sahib is spread over 400 acres with an altitude of 1,552 meters above sea level. Each of the three replicated samples of each genotype of maize was collected, labeled, and transported to the laboratory. The plant roots were washed properly for the removal of adhering soil under running tap water. The bacterial endophytes were isolated using the methods described by Conn and Franco [17], and diverse growth medium were utilized, such as Burks media, tryptic soy agar, Jensen's agar, Kings B agar, yeast mannitol agar, nutrient agar, Azotobacter media, $\mathrm{T}_{3} \mathrm{~A}$ media, Actinomycete isolation agar, and Luria Bertani agar for isolation [18], followed by incubation at $30^{\circ} \mathrm{C}-35^{\circ} \mathrm{C}$. The purified colonies were maintained at $4^{\circ} \mathrm{C}$ in slants and $(25 \%)$ glycerol stock at $-80^{\circ} \mathrm{C}$.

\subsection{Screening of Bacterial Endophytes for PGP-Attributes}

The bacterial endophytes were initially screened for direct PGP attributes, including solubilization of phosphorus on Pikovskaya agar [19], potassium on Alexandrov agar medium [20], and zinc on nutrient agar supplemented with insoluble compounds of zinc [21], respectively. Screening of nitrogen-fixing ability of endophytic microbes was tested by the acetylene reduction assay [22]. The other PGP attributes, indole-3-acetic-acid [23], siderophores [24], and ammonia production [25], were carried out using the standard method. All assays were carried out in triplicate.

\subsubsection{Phosphorus solubilization}

The quantitative estimation of selected bacterial endophytes for solubilization of phosphorus was carried out according to the method described by Murphy and Riley [26]. In $25 \mathrm{ml}$ of the National Botanical Research Institute phosphate medium broth (supplemented with $0.5 \%$ tri-calcium phosphate), $1 \mathrm{ml}$ of bacterial suspension was inoculated and incubated for 1 week at a temperature of $30^{\circ} \mathrm{C}$. A week later, incubated bacterial suspension was centrifuged and the supernatant was collected for phosphorus estimation. To $1 \mathrm{mLl}$ of supernatant, $10 \mathrm{ml}$ of ammonium molybdate solution was added and the volume was made to $45 \mathrm{ml}$ by addition of distilled water which was followed by the addition of 4-5 drops of chlorostannous acid and optical density (OD) at $600 \mathrm{~nm}$. The concentration of $\mathrm{P}$ was expressed in $\mathrm{mg} / \mathrm{L}$.

\subsubsection{Indole-3-Acetic Acid Production}

The quantitative estimation of indole acetic acids (IAA) production was carried out by inoculating $1 \mathrm{ml}$ bacterial suspension in $25 \mathrm{ml}$ of Luria-Bertani (LB) broth. Quantitatively, the IAA production was carried out in two sets, one set of LB broth containing $0.25 \mathrm{M}$ L-tryptophan and the other set without tryptophan incubated at $30^{\circ} \mathrm{C}$ for 3 days. In both sets, Salkowski's reagent was added and observed for the development of pink colorations and IAA concentration was estimated by taking the OD at $530 \mathrm{~nm}$ [23].

\subsubsection{Biological Nitrogen Fixation}

The ability of putative endophytic bacterial culture for nitrogenfixing attributes was carried out using the acetylene reduction assay technique [22]. The nitrogenase activity was expressed as the amount of ethylene produced (in moles) per unit time and cell number. Protein concentration was estimated by Bradford's method [27].

\subsubsection{In-vitro Antagonistic Activity}

The bacterial endophytes property of antagonism was evaluated against Fusarium graminerum. The fungal pathogen was obtained from culture collection at the Division of Microbiology, Indian Agricultural Research Institute, New Delhi, India. 

promotion of maize (Zea mays L.) 2021;9(03):41-50

Table 1: Total viable count of endophytic microbes isolated from different maize genotypes.

\begin{tabular}{lllllllllllll}
\multicolumn{1}{c}{$\begin{array}{c}\text { Maize } \\
\text { Varieties }\end{array}$} & Sample & \multicolumn{1}{c}{ CFU per g of sample (root and shoot) on different media $\left(\times \mathbf{1 0}^{\mathbf{7}}\right)$} \\
\multirow{2}{*}{ LR } & Root & BM & TSA & JM & KBA & YMA & NA & AM & T $_{3} \mathbf{A}$ & AIA & LBA \\
& Stem & 0.48 & 2.89 & 1.28 & 3.30 & 3.48 & 0.38 & 0.25 & 3.20 & 1.20 & 1.05 \\
\multirow{2}{*}{ LW } & Root & 0.32 & 1.42 & 0.74 & 2.20 & 0.93 & 1.09 & 0.58 & 0.92 & 0.93 & 0.91 \\
& Stem & 0.31 & 0.36 & 0.63 & 0.75 & 1.31 & 2.64 & 1.20 & 0.82 & 0.82 & 0.35 \\
\multirow{2}{*}{ Antho } & Root & 0.90 & 0.50 & 0.39 & 0.42 & 0.38 & 0.68 & 0.48 & 0.64 & 0.45 & 1.67 \\
& Stem & 0.39 & 0.33 & 0.31 & 0.38 & 0.42 & 0.77 & 0.67 & 0.57 & 0.31 & 0.91 \\
\hline
\end{tabular}

LR = Local Red; LW = Local White; Anth = Anthocyanin rich; BM = Burks media; TSA = Tryptic soy agar; JM = Jensen's agar; KBA = Kings'

$\mathrm{B}$ Agar; $\mathrm{NA}=$ Nutrient agar; $\mathrm{AM}=$ Azotobacter media; $\mathrm{T}_{3} \mathrm{~A}=\mathrm{T}_{3} \mathrm{~A}$ media; $\mathrm{AIA}=$ Actinomycete isolation agar; $\mathrm{LB}=$ Luria Bertani agar.

\subsection{Evaluation of Endophytic Bacteria on the Growth Promotion of Maize}

Based on the different PGP attributes of bacterial endophytes, strains EU-A2SK1, EU-M4ARAct, and EU-E1RT3-1 were selected for exploring their ability to promote seedling growth of $\mathrm{F}_{1}$ pioneer hybrid maize under greenhouse conditions. Bacterial endophytes were grown overnight in nutrient broth on a rotary shaker at an incubation temperature of $30^{\circ} \mathrm{C}$. All the pots were placed in a completely randomized design in a greenhouse for the avoidance of contamination. For each treatment, there were three replicates. After 1 week of germination, thinning was conducted for the maintenance of two plants per pot. The seedlings were watered properly for maintaining moisture content. At regular periods of 30, 60, and 90 days, the shoot length, number of tillers, and number of spikes were measured. The treatment in the present study consisted of EU-A2SK1, EU-M4ARAct, and EU-E1RT3-1, $50 \% \mathrm{P}$ (half dose of di-ammonium phosphate), 100\% P (full dose of di-ammonium phosphate), and control, respectively.

\subsubsection{Analysis of Biochemical Levels}

The content of chlorophyll and anthocyanin in maize leaves was calculated according to standard method described by Moran and Porath [28] and Mancinelli et al. [29], respectively. For chlorophyll content, $100 \mathrm{mg}$ of fresh maize leaves was placed in a test tube containing $10 \mathrm{ml}$ of methanol: $\mathrm{H}_{2} \mathrm{O}$ :Conc. $\mathrm{HCl}(80: 20: 1 \mathrm{v} / \mathrm{v})$ and placed on a shaker in dark at $4^{\circ} \mathrm{C}$, followed by filtration through Whatman No. 1 filter paper after 72 hours and OD at 530 and $657 \mathrm{~nm}$, respectively. The physiologically available Fe content in the leaves of maize was calculated according to standard method described by Katyal and Sharma [30]. Fresh $100 \mathrm{mg}$ chopped maize leaves were incubated with $25 \mathrm{ml}$ of $1.5 \% 1-10$ O-phenanthroline solution at $25^{\circ} \mathrm{C}$. At $510 \mathrm{~nm}$, the absorbance of the solution was read by the atomic absorption spectrometer. The content of total protein in maize leaves was calculated according to standard method described by Bradford [27]. In $0.5 \%$ trichloroacetic acid, $1 \mathrm{gm}$ of fresh maize leaves were macerated. The OD for determination of protein content was taken at $595 \mathrm{~nm}$. All the statistical analyses were carried out using the XLSTAT program (http://www.xlstat.com).

\subsection{Molecular Characterization of Endophytic Bacteria}

Genomic DNA extraction from the bacterial strains was carried out as per the method described by Verma et al. [31] with some modifications. The PCR amplification of $16 \mathrm{~S}$ rRNA was conducted using the primers pA (5'-AGAGTTTGATCCTGGCTCAG-3') and $\mathrm{pH}$ (5'-AAGGAGGTGATCCAGCCGCA-3'). The amplified 16S rRNA PCR product was selected for the phylogenetic analysis. Furthermore, the Polymerase Chain Reaction (PCR) product of the partial 16S rRNA gene was sequenced at Science of the Genome (SciGenome) (Chennai, India). Using the BLASTn program available at GenBank, the sequences of bacterial endophytes were aligned to those which were already available. A phylogenetic tree was constructed using the neighbor-joining (NJ) method, implemented in the program MEGA 4.0.2 [31]. The partial 16S rRNA sequences were submitted to National Center for Biotechnology Information (NCBI).

\section{RESULTS}

\subsection{Isolation and Enumeration of Bacterial Endophytes}

A total of 67 putative endophytic bacteria were isolated from three maize genotypes grown at Baru Sahib the "Valley of Divine Peace". The population of endophytic bacteria was enumerated using different growth media. The abundance of endophytic bacteria varied from $0.25 \times 10^{7}-3.48 \times 10^{7} \mathrm{CFU} \mathrm{g}^{-1}$ root to $0.30 \times 10^{7}-2.20 \times 10^{7}$ Colony Forming Unit $(\mathrm{CFU}) \mathrm{g}^{-1}$ stem. Among the different media used, yeast mannitol agar supported the highest population of endophytic bacteria $\left(3.48 \times 10^{7} \mathrm{CFU}\right.$ $\mathrm{g}^{-1}$ ) root and the Azotobacter media supported the least growth for the endophytic bacteria $\left(0.25 \times 10^{7} \mathrm{CFU} \mathrm{g^{-1 }}\right.$ root) (Table 1$)$.

\subsection{Screening of Bacterial Endophytes for PGP-Attributes}

Out of the 67 endophytic bacteria, 10 bacterial isolates were selected on the basis of PGP attributes. Out of the 10 endophytic bacteria, all bacterial isolates exhibited PGP attributes of phosphorus and potassium solubilization, whereas only two isolates was positive for zinc solubilization. The production of siderophores, ammonia, and IAA were positive for 7, 5, and 2 bacterial strains, respectively. The nitrogenase activity was demonstrated by two bacterial isolates. Isolate EU-E1RT3-1 solubilized the highest amount of phosphorus $(326.7 \pm 0.08 \mathrm{mg}$ $\left.1^{-1}\right)$ followed by EU-M4ARAct $\left(155.0 \pm 0.20 \mathrm{mg} \mathrm{l}^{-1}\right)$. Isolate EUE1RT3-1 demonstrated highest production of IAA $(21.00 \pm 0.00$ $\mathrm{mg} \mathrm{l}^{-1}$ ) without the addition of tryptophan in screening media; furthermore, the strain EU-A2SK1 produced similar amounts of IAA $\left(21.20 \pm 0.01 \mathrm{mg} / \mathrm{lt}^{-1}\right)$ with the addition of tryptophan 
Table 2: PGP- attributes of endophytic bacteria isolated from maize.

\begin{tabular}{|c|c|c|c|c|c|c|c|c|c|}
\hline \multirow[t]{3}{*}{ Bacterial strain } & \multirow{3}{*}{$\begin{array}{c}\mathbf{N}_{2} \text { Fix. } \\
\text { ARA }\end{array}$} & \multicolumn{2}{|c|}{ Solubilization } & \multirow{3}{*}{$\mathrm{Zn}$} & \multirow{3}{*}{ Sid. } & \multirow{3}{*}{$\mathrm{NH}_{3}$} & \multicolumn{3}{|l|}{ Production } \\
\hline & & \multirow{2}{*}{$P$} & \multirow{2}{*}{$\mathbf{K}$} & & & & & & BC \\
\hline & & & & & & & $(\mathrm{C}+\mathrm{T}+\mathrm{Lb})$ & $(\mathrm{C}-\mathrm{T}+\mathrm{Lb})$ & \\
\hline EU-A2SK1 & + & $114.0 \pm 0.01$ & + & + & + & + & $21.20 \pm 0.01$ & $12.25 \pm 0.01$ & - \\
\hline EU-M4ARAct & + & $155.0 \pm 0.20$ & + & - & - & + & - & - & - \\
\hline EU-E1RT3.1 & - & $326.7 \pm 0.08$ & + & - & + & + & $15.20 \pm 0.00$ & $21.00 \pm 0.00$ & - \\
\hline EU-M2RRN1 & - & + & + & - & - & - & - & - & + \\
\hline EU-MARN2 & - & + & + & - & + & - & - & - & + \\
\hline EU-M3WRLb2 & - & + & + & - & + & - & - & - & - \\
\hline EU-MWSLb10 & - & + & + & - & - & + & - & - & - \\
\hline EU-M6ARLb3 & - & + & + & - & + & - & - & - & - \\
\hline EU-D2SSLb12 & - & + & + & - & + & + & - & - & - \\
\hline EU-B2WSb10 & - & + & + & - & + & - & - & - & - \\
\hline
\end{tabular}

ARA- acetylene reduction assay (nmoles $\mathrm{C}_{2} \mathrm{H}_{4} \mathrm{mg}^{-1}$ protein $\mathrm{hr}^{-1}$ ); P-phosphorus ( $\mathrm{mg} \mathrm{L}^{-1}$ ); K-potassium; Zn-Zinc; Sid-Siderophore; $\mathbf{N H}_{3}$-ammonia; IAA-Indole-3-acetic acid $\left(\mathrm{mg} \mathrm{L}^{-1}\right) \mathrm{C}+\mathrm{T}+\mathrm{Lb}$-Media supplemented with tryptophan, C-T+Lb- Media without tryptophan; BC- biocontrol. [Numerical values are mean \pm standard deviation of the mean (SDm) for three independent observations]

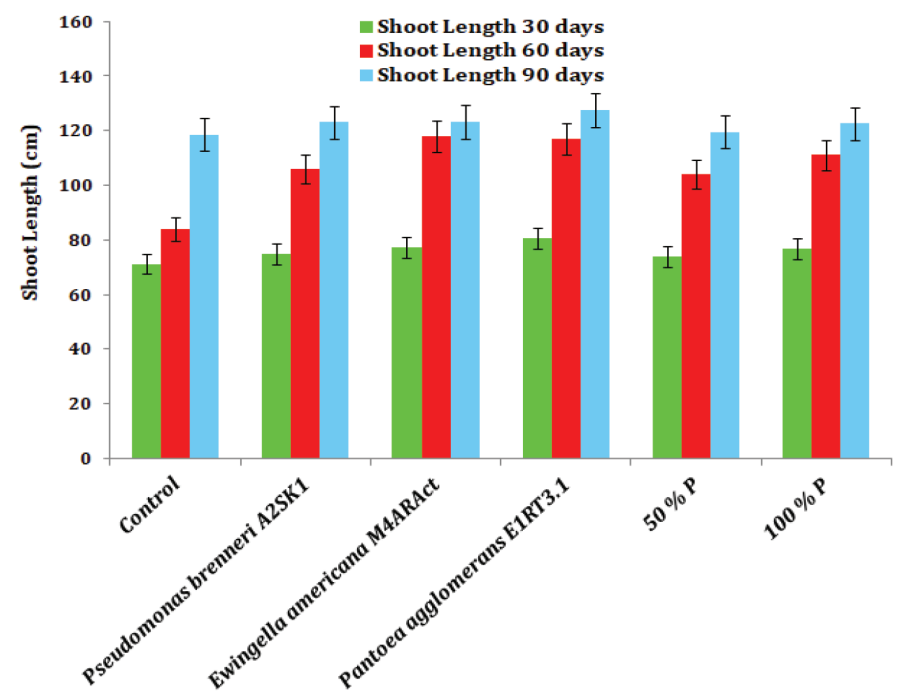

Figure 1: Effect of endophytic bacteria and half (50\%) and full dose (100\%) of phosphorus on the shoot length of pioneer F1 hybrid maize [Phosphorusdiammonium phosphate; Numerical values are mean \pm standard deviation of the mean (SDm) for three independent observations].

during the quantitative estimation of IAA production in LB broth (Table 2).

\subsection{Evaluation of Endophytic Bacteria on Growth Promotion of Maize}

The maize seedlings were bacterized with endophytic bacterial strains EU-A2SK1, EU-M4ARAct, and EU-E1RT3-1. The inoculation of endophytic bacteria and chemical fertilizer (diammonium phosphate) resulted in higher shoot length when compared to the uninoculated control. The treatment of maize seedlings with Pantoea agglomerans EU-E1RT3-1 and Ewingella americana EU-M4ARAct resulted in a significantly higher shoot length when compared to the uninoculated control and other treatments at 30,60, and 90 days. Although both these treatments

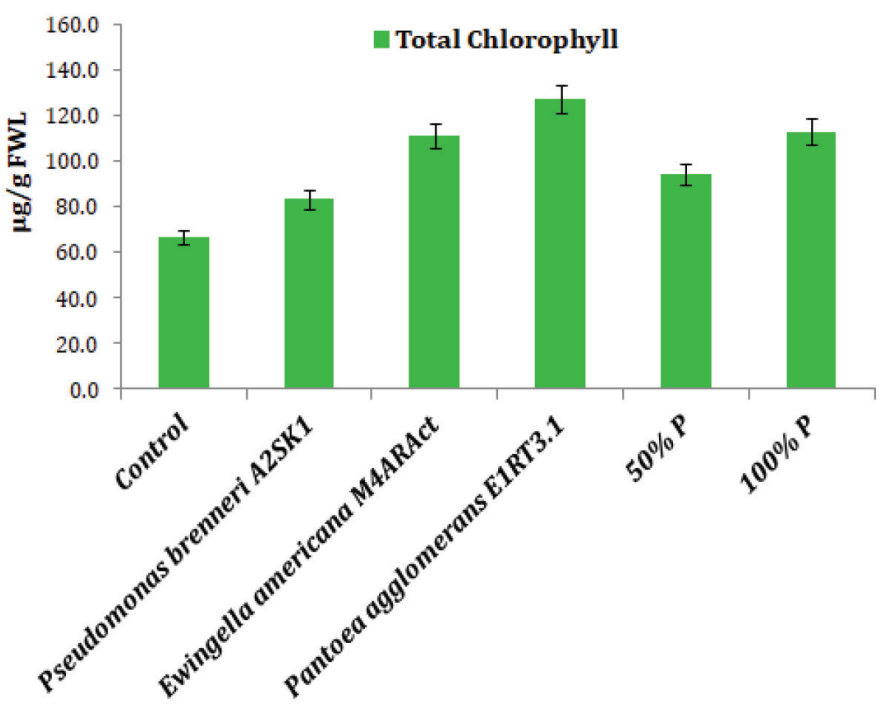

Figure 2: Effect of inoculation of endophytic bacteria, half (50\%) and full dose $(100 \%)$ of phosphorus on chlorophyll content of pioneer F1 hybrid maize [FWL; Phosphorus-diammonium phosphate; Numerical values are mean \pm standard deviation of mean (SDm) for three independent observations].

were statistically analogous, treatment with $P$. agglomerans EUE1RT3-1 resulted in an increased shoot length $(127.5 \mathrm{~cm})$ when compared with E. americana EU-M4ARAct $(123.3 \mathrm{~cm})$ at 90 days, respectively. The treatment of maize seedlings with a full dose $(100 \%)$ of diammonium phosphate (DAP) resulted in an increased shoot length $(122.5 \mathrm{~cm})$ when compared to the half dose $(50 \%)$ of DAP $(119.5 \mathrm{~cm})$ after 90 days (Fig. 1).

The total chlorophyll content was maximum in maize seedlings treated with $P$. agglomerans EU-E1RT3.1 [127.6 $\mu \mathrm{g} / \mathrm{g}$ fresh weight leaf (FWL),], followed by E. americana EU-M4ARAct (111.5 $\mu \mathrm{g} / \mathrm{g}$ FWL), when compared to the uninoculated control (66.8 $\mu \mathrm{g} / \mathrm{g}$ FWL) after 60 days (Fig. 2). In the present study, bacterized maize seedlings after 60 days of plant growth revealed a maximum increase in the anthocyanin content compared to the uninoculated 


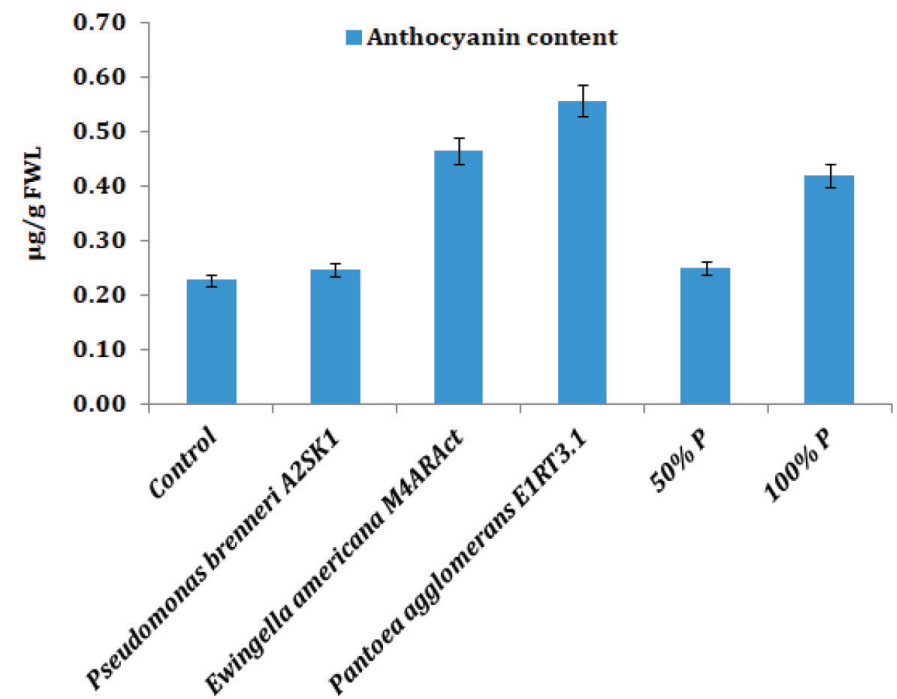

Figure 3: Effect of inoculation of endophytic bacteria, half (50\%) and full dose $(100 \%)$ of phosphorus $(\mathrm{P})$ on anthocyanin content of pioneer F1 hybrid maize

[FWL; Phosphorus-diammonium phosphate; Numerical values are mean \pm standard deviation of mean (SDm) for three independent observations].

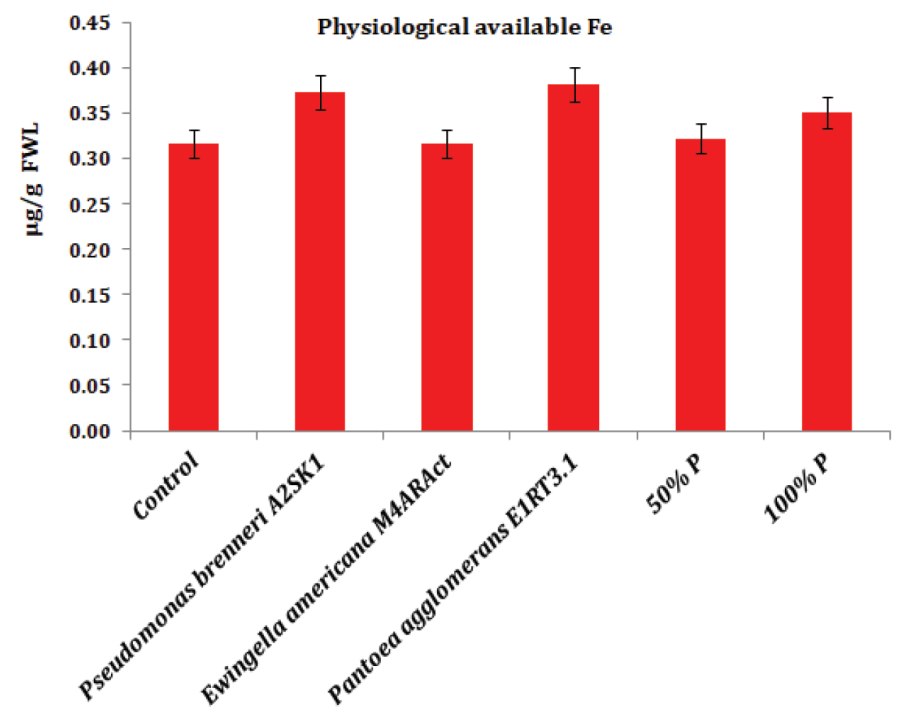

Figure 4: Effect of inoculation of endophytic bacteria, half (50\%) and full dose $(100 \%)$ of phosphorus on physiologically available Fe of pioneer F1 hybrid maize [FWL; Phosphorus-diammonium phosphate; Numerical values are mean \pm standard deviation of mean (SDm) for three independent observations].

control. Maximum enhancement of anthocyanin content was found in $P$. agglomerans EU-E1RT3.1 $(0.56 \mu \mathrm{g} / \mathrm{g}$ FWL) treated plants, followed by $E$. americana EU-M4ARAct $(0.46 \mu \mathrm{g} / \mathrm{g}$ FWL $)$ compared to the uninoculated control plants $(0.23 \mu \mathrm{g} / \mathrm{g}$ FWL $)$ (Fig. 3). Maize seedlings bacterized with $P$. agglomerans EUE1RT3.1 (twofold) showed enhancement in the physiologically available Fe content, followed by Pseudomonas brenneri EUA2SK1 when compared to the uninoculated control. However, a full dose $(100 \%)$ of DAP also played a significant role in reducing the deficiency of $\mathrm{Fe}$ compared to the uninoculated control (Fig. 4). The study on the total protein content in the maize leaves was carried out after 60 days. The total protein content was found

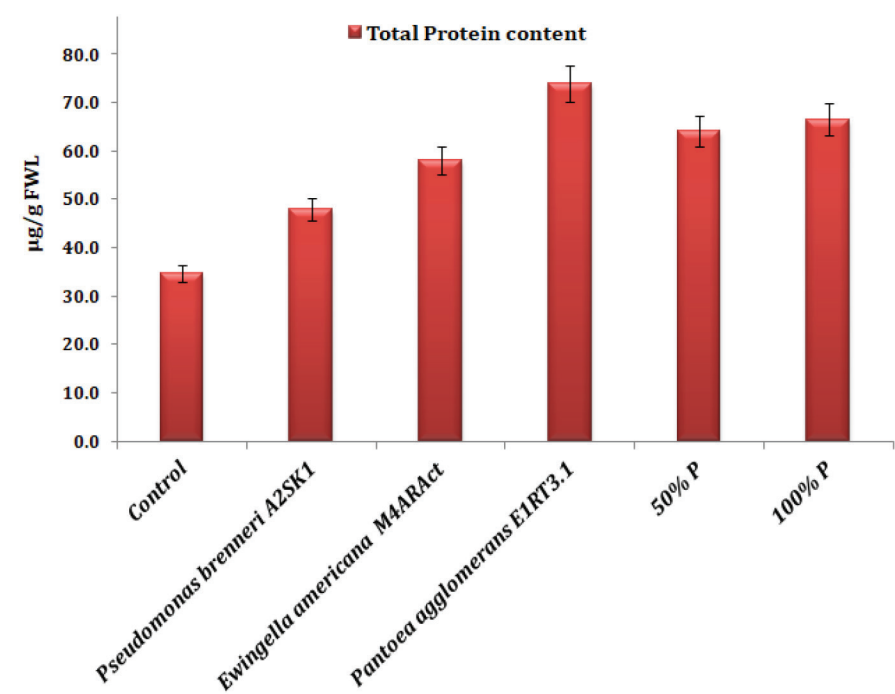

Figure 5: Effect of inoculation of endophytic bacteria, half (50\%) and full dose $(100 \%)$ of phosphorus on total protein content of pioneer $\mathrm{F} 1$ hybrid maize

[FWL; Phosphorus-diammonium phosphate; Numerical values are mean \pm standard deviation of mean (SDm) for three independent observations].

to be higher in maize seedlings bacterized with $P$. agglomerans EU-E1RT3.1 compared with the uninoculated control. However, half $(50 \%)$ and full $(100 \%)$ doses of DAP also demonstrated significant enhancement of protein content (Fig. 5)

\subsection{Molecular Characterization and Phylogenetic Analysis}

The taxonomic position of endophytic bacterial isolates was determined by comparing the $16 \mathrm{~S}$ rRNA gene sequence with different strains obtained from the NCBI database using the BLASTn search. The $16 \mathrm{~S}$ rRNA gene identification revealed that the endophyte EU-A2SK1, EU-M4ARAct, and EU-E1RT3.1 showed maximum similarity with $P$. brenneri, E. americana, and $P$. agglomerans, respectively. A phylogenetic tree was generated using the sequences from EU-A2SK1, EU-M4ARAct, and EU-E1RT3-1 and representative sequences from the NCBI databases. The nucleotide sequences determined in this work have been deposited in the GenBank database with accession numbers MN294531, MN294547, and MN294552 for isolates EU-A2SK1, EU-M4ARAct, and EU-E1RT3-1, respectively (Fig. 6).

\section{DISCUSSION}

The advancement in plant-microbe interactions, the isolation, and characterization of microbes with various PGP attributes is fundamentally important due to their potential applications in agriculture. In many regions around the world, the utilization of PGP as bioinoculants is one of the alternative ways for reducing the usage of chemical fertilizers [32]. The diversity of endophytic bacteria associated with different plants, namely maize [33], potato [34], sugarcane [35], soybean [36], wheat [37], and barley [38], has been reported worldwide. In the present investigation, we describe the endophytic bacteria from maize and their PGP attributes. Maize plants inoculated with endophytic bacteria resulted in enhanced shoot length and biochemical content, namely 


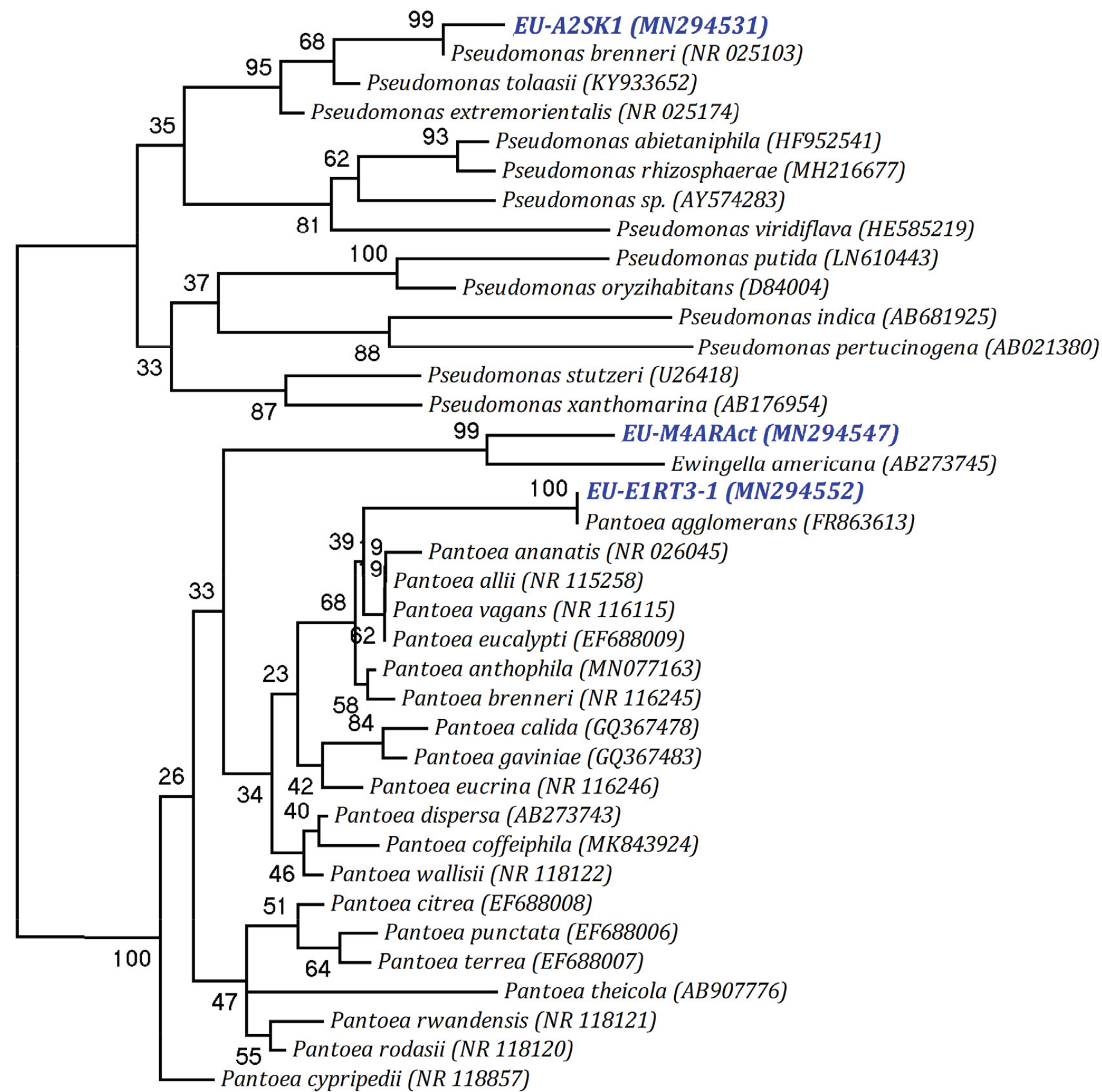

0.01

Figure 6: Phylogenetic tree showing the relationship of EU-A2SK1, EU-M4ARAct, and EU-E1RT3-1 with reference sequences obtained from NCBI through BLAST search. The sequence alignment was carried out using the CLUSTAL W program and the tree was constructed using the neighbor-NJ with algorithm using MEGA4 software.

chlorophyll, anthocyanin, physiologically available Fe, and total protein content. In our study, the efficient strains were identified as P. brenneri, E. americana, and P. agglomerans by $16 \mathrm{~S}$ rRNA gene sequencing which belonged to phylum Proteobacteria and class Gammaproteobacteria.
Phosphorus is a reactive element and mostly exists in two different forms in the soil, as insoluble organic and inorganic phosphorus [39]. In the soil, P mostly gets immobilized by cations, such as $\mathrm{Ca}^{2+}, \mathrm{Al}^{3+}, \mathrm{Fe}^{3+}$, and $\mathrm{Mg}^{2+}$, depending on the properties of soil whether acidic or calcareous in nature. The insoluble form of 
phosphorus is highly unavailable to the plants [40,41]. In the present study, we found that $P$. agglomerans solubilized the highest amount of phosphorus and we strongly suspect that endophytic bacterium solubilizing the highest amount of $\mathrm{P}$ could have further played a strong role in the growth promotion of pioneer F1 hybrid maize. In the present investigation, $\mathrm{P}$-solubilization activity was also exhibited by endophytic $P$. brenneri and E. americana. The endophytic bacteria belonging to genera Bacillus, Klebsiella, Microbacterium Pantoea, Paenibacillus, and Pseudomonas, as endophytes have been already reported to solubilize P $[42,43]$. Diversity of P-solubilizing endophytes has been reported from maize $[13,44,45]$. Thus, the microbes with the ability to solubilize phosphorus play a vital role in converting the insoluble form of phosphorus to the soluble form.

The interaction among bacteria and plants is a complex phenomenon. Among the PGP attributes, the production of IAA affects the physiology of plants, such as stimulation of seed germination and the development of lateral and adventitious root, affects photosynthesis, formation of pigments, and biosynthesis of various metabolites [46]. In this study, we found that $P$. agglomerans produced higher concentration of IAA $(21.00 \pm 0.00$ $\mathrm{mg}^{-1}$ ) in medium without tryptophan, whereas $P$. brenneri showed maximum IAA production $\left(21.20 \pm 0.01 \mathrm{mg} \mathrm{l}^{-1}\right)$ in media amended with tryptophan. Various studies have already demonstrated the production of indolic compounds in bacteria [47]. The bacteria of different species utilize different pathways for IAA biosynthesis. Bacteria-synthesizing IAA belonging to different genera are well known to utilize tryptophan as a main precursor for IAA biosynthesis pathways [48]. Pantoea sp. CCBAU15488 was reported to be able to nodulate soybean and was also recorded for production of IAA on the basis of intensity of red color [49]. Production of IAA in the past has received maximum interest of scientists. An endophytic P. agglomerans isolated from Oryza sativa $\mathrm{cv}$. Yuefu has been reported to enhance the growth of host plant in field application and is known to synthesize indole3 -acetic acid $\left(243 \mathrm{ng} \mathrm{ml}^{-1}\right)$, and also affects allocations of host photosynthates [50]. The study of Etesami et al. [51] reported an IAA-producing endophytic bacterium Pseudomonas putida CEN7 from berseem clover plants nodules. Yu et al. [52] reported IAAproducing Psychrobacillus, Microbacterium, Lysinibacillus, and Bacillus from maize root.

In the growth and development of plants, potassium plays a vital role which also provides ionic environment for metabolic process in the cytosol. In the soil, $\mathrm{K}$ is present in different forms, such as muscovite, orthoclase, biotite, feldspar, illite, and vermiculite. The major amount of $\mathrm{K}$ available in the soil is not available to the plant, which further leads to deficiency of $\mathrm{K}$ in the crops. It has been reported that microbes solubilizing $\mathrm{K}$, which are present in the soil, enhance the bioavailability of $\mathrm{K}$ to plants through different mechanisms, namely decomposition, mineralization, and release of nutrients [53]. The endophytic bacteria belonging to genera Alcaligenes, Acinetobacter, Achromobacter, Bacillus, Enterobacter, and Microbacterium isolated from different host plant have been reported as K-solubilizing bacteria [54-56]. In the present study, $P$. agglomerans EU-E1RT3.1, P. brenneri EU-A2SK1, and E. americana EU-M4ARAct were found to solubilize potassium. Zinc is another essential micronutrient required in low concentrations by plants, but is toxic at higher concentrations, essentially required for chlorophyll synthesis. Bacteria solubilizing different insoluble compounds of zinc have an immense role in providing nutrition to plants [57]. In the present study, P. brenneri EU-A2SK1 is reported as $\mathrm{Zn}$ solubilizing bacteria.

The indirect method of plant growth promotion includes the siderophores and ammonia production. In the present study, endophytic bacterial strains were also siderophore and ammonia producers. The production of siderophore by microorganisms is one of the vital attribute, as microbes bind to the available form of iron $\left(\mathrm{Fe}^{3+}\right)$ and scavenge the phytopathogens from iron availability and their noxious impact on plant health. In earlier studies, the production of ammonia has been reported to be involved in the pathogen-inhibition mechanism, which indirectly influences the growth of plants [58,59]. In a study, it was reported that endophytic bacteria identified as Agrobacterium larrymoorei, Bacillus sp., Bacillus aryabhattai, Bacillus cereus, Bacillus amyloliquefaciens, Bacillus licheniformis, Klebsiella sp., Klebsiella variicola, Lactococcus lactis, Pantoea cypripedii, Pantoea dispersa, Pantoea sp., and Staphylococcus hominis were seen enhancing the $\mathrm{P}, \mathrm{K}, \mathrm{Zn}$ solubilization, producing hormones, siderophore, 1-aminocyclopropane-1-carboxylate deaminase, hydrogen cyanide $(\mathrm{HCN})$, fixings biological nitrogen, and were showing antagonist activity against two fungal pathogen of maize [60].

In the present investigation, pot culture experiments were carried out to evaluate the effect of endophytic bacteria on pioneer $F_{1}$ hybrid maize seedling which revealed a significant growth enhancement parameter and biochemical levels. Pioneer $F_{1}$ hybrid maize seedlings bacterized with endophytic bacteria $P$. agglomerans EUE1RT3.1 demonstrated an enhanced shoot length when compared to non-bacterized control. Most studies have demonstrated plant growth promotion in bacterized plants compared to the uninoculated controls [61]. In the study of Montañez [13], maize inoculated with endophytic bacteria significantly enhanced the plant growth under controlled conditions. The study of Lobo et al. [62] demonstrated the growth promotion of maize with the treatment of endophytic bacteria.

The higher photosynthetic rate in plants is directly related to the content of chlorophyll. In the present study, the chlorophyll content was observed to be higher in inoculated plants. Colonization of Beta vulgaris L. by endophytic bacteria was observed to improve the rate of photosynthesis with maximal photochemical efficiency even at increasing photosynthetic photon flux density, which results in the enhancement of the chlorophyll synthesis with positive effects on root and aerial part growth [63]. The higher content of chlorophyll is valuable in achieving a high rate of photosynthesis, which eventually resulted in a higher yield and productivity and healthy plant growth [64]. The higher photosynthetic ability is directly related to the upregulation of genetic expression in plants by endophytic microbes, which increases the leaf area and enhances the total amount of photosynthesis [65].

In the promotion of plants growth, biochemical changes mostly take place. In the plants, anthocyanin are the secondary metabolites that are extensively distributed in plants and plays 
an important role in signaling between plants and microbes, modulate synthesis of phytohormone auxin and its transport, and also plays vital function in antioxidant activity [66]. Decreased levels of anthocyanin in plants are directly related to the chilling sensitivity of plants [67]. In a finding, beneficial bacterial application significantly enhanced the total content of anthocyanin in strawberry fruits as compared to control. Besides improving the fertility of soil, microbes play an efficient role in fortifying the iron contents in plants through production of siderophores [68]. The transporter proteins located on plasma membrane of root and translocate the iron chelate complex toward the plant [69]. Therefore, for the improvement of content of iron in different edible plants biofortification of plant through endophytic microbes is measured in a safe way. Inoculations of wheat genotype 4HPYT-414 with Arthrobacter sulfonivorans, the siderophores-producing endophyte, facilitate the higher translocation of Fe in roots and shoots [70].

An interesting modification caused by inoculation with endophytic bacteria observed was significant enhancement in total soluble protein. Against the various environmental stress conditions, plants mostly adapt with adjustments in several compatible organic solutes, changes in expression of protein, accumulation, and synthesis $[71,72]$. In the present investigation, evidences for the enhanced levels of chlorophyll, anthocyanin, physiologically available $\mathrm{Fe}$ and total protein content in the maize plants treated with endophytic bacteria agree with the earlier studies and indicate that these biomarkers efficiently play a significant role in the plant growth promotion. We, therefore, conclude that endophytic bacteria-mediated responses in plant leaves and increased concentration of biochemical levels played a cumulative synergistic function that improved the growth of pioneer $\mathrm{F}_{1}$ hybrid maize. To the best of our knowledge, P. agglomerans EU-E1RT3.1 has been reported for the first time for enhancing growth and physiological parameters of maize.

In conclusion, we found that endophytes served as a valuable pool of bacteria with PGP- abilities. According to the results obtained in this study, strain $P$. agglomerans EU-E1RT3-1, possessing the capacity for $\mathrm{P}$ and $\mathrm{K}$ solubilization, and IAA production successfully improved plant growth. The strain with multiple PGP activities reported in this investigation seems to be an ideal candidate as a bioinoculant. P. agglomerans EU-E1RT3-1 in future may be used as an efficient biofertilizer for improving the health and productivity of crops. However, further studies must be conducted for the commercial scale production of NPK-based biofertilizers.

\section{ACKNOWLEDGMENTS}

The authors are grateful to the Department of Biotechnology, Dr. Khem Singh Gill Akal College of Agriculture, Eternal University, Baru Sahib and Department of Environment, Science and Technology, Shimla, for funding the project - "Development of microbial consortium as bio-inoculants for drought and low temperature growing crops for organic farming in Himachal Pradesh" - and for providing the facilities and financial support to undertake the investigations.

\section{AUTHOR CONTRIBUTIONS}

All authors made substantial contributions to conception and design, acquisition of data, or analysis and interpretation of data; took part in drafting the article or revising it critically for important intellectual content; agreed to submit to the current journal; gave final approval of the version to be published; and agree to be accountable for all aspects of the work. All the authors are eligible to be an author as per the international committee of medical journal editors (ICMJE) requirements/guidelines.

\section{CONFLICTS OF INTEREST}

The authors report no financial or any other conflicts of interest in this work.

\section{ETHICAL APPROVALS}

Not applicable.

\section{PUBLISHER'S NOTE}

This journal remains neutral with regard to jurisdictional claims in published institutional affiliation.

\section{REFERENCES}

1. Gibbon D, Pain A. Crops of the drier regions of the tropics. Longman, London, UK, 1985.

2. Ranum P, Peña-Rosas JP, Garcia-Casal MN. Global maize production, utilization, and consumption. Ann N Y Acad Sci 2014;1312:105-12; doi:10.1111/nyas. 12396

3. Onasanya R, Aiyelari O, Onasanya A, Nwilene F, Oyelakin O. Effect of different levels of nitrogen and phosphorus fertilizers on the growth and yield of maize (Zea mays L.) in Southwest Nigeria. Int J Agric Res 2009;4:193-203.

4. Singh B, Boukhris I, Pragya KV, Yadav AN, Farhat-Khemakhem A Kumar A, et al. Contribution of microbial phytases to the improvement of plant growth and nutrition: a review. Pedosphere 2020;30(3):295-313.

5. Kour D, Rana KL, Yadav AN, Yadav N, Kumar M, Kumar V, et al Microbial biofertilizers: bioresources and eco-friendly technologies for agricultural and environmental sustainability. Biocatal Agric Biotechnol 2020;23:101487.

6. Mondal S, Halder SK, Yadav AN, Mondal KC. Microbial consortium with multifunctional plant growth promoting attributes: future perspective in agriculture. In: Yadav AN, Rastegari AA, Yadav N, Kour D (eds.). Advances in plant microbiome and sustainable agriculture, volume 2: functional annotation and future challenges. Springer, Singapore, pp 219-54, 2020.

7. Compant S, Clément C, Sessitsch A. Plant growth-promoting bacteria in the rhizo-and endosphere of plants: their role, colonization, mechanisms involved and prospects for utilization. Soil Biol Biochem 2010;42:669-78; doi:10.1016/j.soilbio.2009.11.024

8. Rosenblueth M, Martínez-Romero E. Bacterial endophytes and their interactions with hosts. Mol Plant Microbe Interact 2006;19: 827-37.

9. Yadav AN, Kour D, Kaur T, Devi R, Gukeria G, Rana KL, et al. Microbial biotechnology for sustainable agriculture: current research and future challenges. In: Rastegari AA, Yadav AN, Yadav N (eds.). Trends of microbial biotechnology for sustainable agriculture and biomedicine systems: diversity and functional perspectives. Elsevier, Amsterdam, Netherlands, pp 331-43, 2020.

10. Thakur N, Kaur S, Tomar P, Thakur S, Yadav AN. Microbial biopesticides: current status and advancement for sustainable agriculture and environment. In: Rastegari AA, Yadav AN, Yadav N 
(eds.). Trends of microbial biotechnology for sustainable agriculture and biomedicine systems: diversity and functional perspectives. Elsevier, Amsterdam, Netherlands, pp 243-82, 2020.

11. Figueiredo JEF, Gomes EA, Guimarães CT, Lana UGdP, Teixeira MA, Lima GVC, et al. Molecular analysis of endophytic bacteria from the genus Bacillus isolated from tropical maize (Zea mays L.). Braz J Microbiol 2009;40:522-34; doi:10.1590/S151783822009000300014

12. Ikeda AC, Bassani LL, Adamosk D, Stringari D, Cordeiro VK, Glienke $\mathrm{C}$, et al. Morphological and genetic characterization of endophytic bacteria isolated from roots of different maize genotypes. Microb Ecol 2013;65:154-60; doi:10.1007/s00248-012-0104-0

13. Montañez A, Blanco AR, Barlocco C, Beracochea M, Sicardi M. Characterization of cultivable putative endophytic plant growth promoting bacteria associated with maize cultivars (Zea mays L.) and their inoculation effects in vitro. Appl Soil Ecol 2012;58:21-8; doi:10.1016/j.apsoil.2012.02.009

14. Kour D, Rana KL, Yadav N, Yadav AN, Kumar A, Meena VS, et al. Rhizospheric microbiomes: biodiversity, mechanisms of plant growth promotion, and biotechnological applications for sustainable agriculture. In: Kumar A, Meena VS (eds.). Lant growth promoting rhizobacteria for agricultural sustainability: from theory to practices. Springer, Singapore, pp 19-65, 2019.

15. Suman A, Yadav AN, Verma P. Endophytic microbes in crops: diversity and beneficial impact for sustainable agriculture. In: Singh DP, Singh HB, Prabha R (eds.). Microbial inoculants in sustainable agricultural productivity: Vol 1: research perspectives. Springer, Delhi, India, pp 117-43; 2016

16. Príncipe A, Alvarez F, Castro MG, Zachi L, Fischer SE, Mori GB, et al. Biocontrol and PGPR features in native strains isolated from saline soils of Argentina. Curr Microbiol 2007;55:314-22; doi:10.1007/ s00284-006-0654-9

17. Conn VM, Franco CM. Effect of microbial inoculants on the indigenous actinobacterial endophyte population in the roots of wheat as determined by terminal restriction fragment length polymorphism. Appl Environ Microbiol 2004;70:6407-13; doi:10.1128/ AEM.70.11.6407-6413.2004

18. Verma P, Yadav AN, Khannam KS, Kumar S, Saxena AK, Suman A. Molecular diversity and multifarious plant growth promoting attributes of Bacilli associated with wheat (Triticum aestivum L.) rhizosphere from six diverse agro-ecological zones of India. J Basic Microbiol 2016;56:44-58; doi:10.1002/jobm.201500459

19. Pikovskaya R. Mobilization of phosphorus in soil in connection with vital activity of some microbial species. Mikrobiologya 1948;17:36270

20. Hu X, Chen J, Guo J. Two phosphate-and potassium-solubilizing bacteria isolated from Tianmu Mountain, Zhejiang, China. World J Microbiol Biotechnol 2006;22:983-90; doi:10.1007/s11274-0069144-2

21. Fasim F, Ahmed N, Parsons R, Gadd GM. Solubilization of zinc salts by a bacterium isolated from the air environment of a tannery. FEMS Microbiol Lett 2002;213:1-6; doi:10.1111/j.1574-6968.2002. tb11277.x

22. Han SO, New P. Variation in nitrogen fixing ability among natural isolates of Azospirillum. Microb Ecol 1998;36:193-201.

23. Patten CL, Glick BR. Role of Pseudomonas putida indoleacetic acid in development of the host plant root system. Appl Environ Microbiol 2002;68:3795-801; doi:10.1128/AEM.68.8.3795-3801.2002

24. Schwyn B, Neilands J. Universal chemical assay for the detection and determination of siderophores. Anal Biochem 1987;160:47-56; doi:10.1016/0003-2697(87)90612-9

25. Cappucino J, Sherman N. Nitrogen cycle. Microbiology: a laboratory manual. 4th edition, Benjamin/Cumming, New York, NY, pp 311-2, 1992.

26. Murphy J, Riley JP. A modified single solution method for the determination of phosphate in natural waters. Anal Chim Acta 1962;27:31-6.
27. Bradford MM. A rapid and sensitive method for the quantitation of microgram quantities of protein utilizing the principle of protein-dye binding. Anal Biochem 1976;72:248-54.

28. Moran R, Porath D. Chlorophyll determination in intact tissues using N, N-dimethylformamide. Plant Physiol 1980;65:478-9; doi:10.1104/ pp.65.3.478

29. Mancinelli A, Yang CPH, Lindquist P, Anderson O, Rabino I. Photocontrol of anthocyanin synthesis: III. The action of streptomycin on the synthesis of chlorophyll and anthocyanin. Plant Physiol $1975 ; 55: 251-7$

30. Katyal J, Sharma B. A new technique of plant analysis to resolve iron chlorosis. Plant Soil 1980;55:105-19.

31. Verma P, Yadav AN, Khannam KS, Panjiar N, Kumar S, Saxena AK, et al. Assessment of genetic diversity and plant growth promoting attributes of psychrotolerant bacteria allied with wheat (Triticum aestivum) from the northern hills zone of India. Ann Microbiol 2015;65:1885-99; doi:10.1007/s13213-014-1027-4

32. Okon Y, Bloemberg GV, Lugtenberg BJ. Biotechnology of biofertilization and phytostimulation. Agric Biotechnol 1998;327:349.

33. Gutiérrez-Zamora M, Martınez-Romero E. Natural endophytic association between Rhizobium etli and maize (Zea mays L.). J Biotechnol 2001;91:117-26; doi:10.1016/S0168-1656(01)00332-7

34. Sessitsch A, Reiter B, Pfeifer U, Wilhelm E. Cultivationindependent population analysis of bacterial endophytes in three potato varieties based on eubacterial and Actinomycetes-specific PCR of 16S rRNA genes. FEMS Microbiol Ecol 2002;39:23-32; doi:10.1111/j.1574-6941.2002.tb00903.x

35. Loiret F, Ortega E, Kleiner D, Ortega-Rodés P, Rodes R, Dong Z. A putative new endophytic nitrogen-fixing bacterium Pantoea sp. from sugarcane. J Appl Microbiol 2004;97:504-11; doi:10.1111/j.13652672.2004.02329.x

36. Hung PQ, Annapurna K. Isolation and characterization of endophytic bacteria in soybean (Glycine sp.). Omonrice 2004;12:92-101.

37. Jha P, Kumar A. Characterization of novel plant growth promoting endophytic bacterium Achromobacter xylosoxidans from wheat plant. Microb Ecol 2009;58:179-88; doi:10.1007/s00248-009-9485-0

38. Zawoznik M, Vázquez SC, Díaz Herrera SM, Groppa MD. Search for endophytic diazotrophs in barley seeds. Braz J Microbiol 2014;45:621-5; doi:10.1590/S1517-83822014000200033

39. Yadav AN, Sharma D, Gulati S, Singh S, Dey R, Pal KK, Kaushik R, Saxena AK. Haloarchaea endowed with phosphorus solubilization attribute implicated in phosphorus cycle. Scientific Reports. 2015; 5(1):12293.

40. Kour D, Rana KL, Kaur T, Yadav N, Yadav AN, Kumar M, Kumar V, et al. Biodiversity, current developments and potential biotechnological applications of phosphorus-solubilizing and -mobilizing microbes: A review. Pedosphere. 2021; 31(1):43-75. https://doi.org/10.1016/ S1002-0160(20)60057-1

41. Kour D, Kaur T, Yadav N, Rastegari AA, Singh B, Kumar V, et al. Phytases from microbes in phosphorus acquisition for plant growth promotion and soil health. In: Rastegari AA, Yadav AN, Yadav N (eds.). Trends of microbial biotechnology for sustainable agriculture and biomedicine systems: diversity and functional perspectives. Elsevier, Amsterdam, Netherlands, pp 157-76, 2020.

42. Kour D, Rana KL, Kaur T, Sheikh I, Yadav AN, Kumar V, et al. Microbe-mediated alleviation of drought stress and acquisition of phosphorus in great millet (Sorghum bicolour L.) by drought-adaptive and phosphorus-solubilizing microbes. Biocatal Agric Biotechnol 2020;23:101501.

43. Kour D, Rana KL, Yadav AN, Sheikh I, Kumar V, Dhaliwal HS, et al. Amelioration of drought stress in Foxtail millet (Setaria italica L.) by P-solubilizing drought-tolerant microbes with multifarious plant growth promoting attributes. Environ Sustain 2020;3(1) 23-34.

44. De Abreu C, Figueiredo J, Oliveira C, Dos Santos V, Gomes E, Ribeiro $\mathrm{V}$ et al. Maize endophytic bacteria as mineral phosphate solubilizers. Genet Mol Res 2017;16(1):1-7; doi: 10.4238/gmr16019294 
45. Ali S, Isaacson J, Kroner Y, Saldias S, Kandasamy S, Lazarovits G. Corn sap bacterial endophytes and their potential in plant growthpromotion. Environ Sustain 2018;1:341-55.

46. Spaepen S, Vanderleyden J. Auxin and plant-microbe interactions. Cold Spring Harb Perspect Biol 2011;3:a001438; doi:10.1101/ cshperspect.a001438

47. Yim WJ, Poonguzhali S, Madhaiyan M, Palaniappan P, Siddikee $\mathrm{M}$, Sa T. Characterization of plant-growth promoting diazotrophic bacteria isolated from field grown Chinese cabbage under different fertilization conditions. J Microbiol 2009;47:147-55; doi:10.1007/ s12275-008-0201-4

48. Spaepen S, Vanderleyden J, Remans R. Indole-3-acetic acid in microbial and microorganism-plant signaling. FEMS Microbiol Rev 2007;31:425-48; doi:10.1111/j.1574-6976.2007.00072.x

49. Li JH, Wang ET, Chen WF, Chen WX. Genetic diversity and potential for promotion of plant growth detected in nodule endophytic bacteria of soybean grown in Heilongjiang province of China. Soil Biol Biochem 2008;40:238-46; doi:10.1016/j.soilbio.2007.08.014

50. Feng Y, Shen D, Song W. Rice endophyte Pantoea agglomerans YS19 promotes host plant growth and affects allocations of host photosynthates. J Appl Microbiol 2006;100:938-45; doi:10.1111/ j.1365-2672.2006.02843.x

51. Etesami H, Hosseini HM, Alikhani HA, Mohammadi L. Bacterial biosynthesis of 1-aminocyclopropane-1-carboxylate (ACC) deaminase and indole-3-acetic acid (IAA) as endophytic preferential selection traits by rice plant seedlings. J Plant Growth Regul 2014;33:654-70; doi:10.1007/s00344-014-9415-3

52. Yu J, Yu Z, Fan G, Wang G, Liu X. Isolation and characterization of indole acetic acid producing root endophytic bacteria and their potential for promoting crop growth. J Agric Sci Tech 2016;18: 1381-91.

53. Rajawat MVS, Singh R, Singh D, Yadav AN, Singh S, Kumar M, et al. Spatial distribution and identification of bacteria in stressed environments capable to weather potassium aluminosilicate mineral. Braz J Microbiol 2020;51(2):751-64.

54. Verma P, Yadav AN, Khannam KS, Mishra S, Kumar S, Saxena AK, et al. Appraisal of diversity and functional attributes of thermotolerant wheat associated bacteria from the peninsular zone of India. Saudi J Biol Sci 2019;26(7):1882-95.

55. Kour D, Rana KL, Kaur T, Devi R, Yadav N, Halder SK, et al. Potassium solubilizing and mobilizing microbes: biodiversity, mechanisms of solubilization and biotechnological implication for alleviations of abiotic stress. In: Rastegari AA, Yadav AN, Yadav N (Eds). Trends of microbial biotechnology for sustainable agriculture and biomedicine systems: diversity and functional perspective. Elsevier, Amsterdam, Netherlands, pp 177-202, 2020.

56. Verma P, Yadav AN, Kazy SK, Saxena AK, Suman A. Evaluating the diversity and phylogeny of plant growth promoting bacteria associated with wheat (Triticum aestivum) growing in central zone of India. Int J Curr Microbiol Appl Sci 2014;3(5):432-47.

57. Saravanan V, Kalaiarasan P, Madhaiyan M, Thangaraju M. Solubilization of insoluble zinc compounds by Gluconacetobacter diazotrophicus and the detrimental action of zinc ion $\left(\mathrm{Zn}^{2+}\right)$ and zinc chelates on root knot nematode Meloidogyne incognita. Lett Appl Microbiol 2007;44:235-41; doi:10.1111/j.1472-765X.2006.02079.x

58. Kremer RJ, Souissi T. Cyanide production by rhizobacteria and potential for suppression of weed seedling growth. Curr Microbiol 2001;43:182-6; doi:10.1007/s002840010284

59. Yadav AN, Sachan SG, Verma P, Saxena AK. Bioprospecting of plant growth promoting psychrotrophic Bacilli from cold desert of north western Indian Himalayas. Indian J Exp Biol 2016;54(2): $142-50$
60. Marag PS, Yadav AN, Suman A. Growth stage and tissue specific colonization of endophytic bacteria having plant growth promoting traits in hybrid and composite maize (Zea mays L.). Microbiol Res 2018;214:101-13; doi:10.1016/j.micres.2018.05.016

61. Yadav AN. Microbiomes of wheat (Triticum aestivum L.) endowed with multifunctional plant growth promoting attributes. EC Microbiol 2019;15(4):1-6.

62. Lobo LLB, dos Santos RM, Rigobelo EC. Promotion of maize growth using endophytic bacteria under greenhouse and field conditions. Aust J Crop Sci 2019;13:2067.

63. Shi Y, Lou K, Li C. Growth and photosynthetic efficiency promotion of sugar beet (Beta vulgaris L.) by endophytic bacteria. Photosynth Res 2010;105:5-13; doi:10.1007/s11120-010-9547-7

64. Joshi D, Chandra R, Suyal DC, Kumar S, Goel R. Impacts of bioinoculants Pseudomonas jesenii MP1 and Rhodococcus qingshengi S10107 on chickpea (Cicer arietinum L.) yield and soil nitrogen status. Pedosphere 2019;29:388-99; doi:10.1016/S1002-0160(19)60807-6

65. Harman GE, Uphoff N. Symbiotic root-endophytic soil microbes improve crop productivity and provide environmental benefits. Scientifica 2019;2019:9106395; doi:10.1155/2019/9106395.

66. Jia H, Wang Ja, Yang Y, Liu G, Bao Y, Cui H. Changes in flavonol content and transcript levels of genes in the flavonoid pathway in tobacco under phosphorus deficiency. Plant Growth Regul 2015;76:225-31; doi:10.1007/s10725-014-9990-0

67. Saltveit ME. Discovery of chilling injury. In: Shain-Dow K, Shang-Fa Y (eds.). Discoveries in plant biology: volume III. World Scientific, Singapore, pp 423-48, 2000.

68. Kaur T, Rana KL, Kour D, Sheikh I, Yadav N, Kumar V, et al. Microbemediated biofortification for micronutrients: present status and future challenges. In: Rastegari AA, Yadav AN, Yadav N (eds.). Trends of microbial biotechnology for sustainable agriculture and biomedicine systems: perspectives for human health. Elsevier, Amsterdam, Netherlands, pp 1-17, 2020.

69. Boukhalfa H, Crumbliss AL. Chemical aspects of siderophore mediated iron transport. Biometals 2002;15:325-39; doi:10.1023/ A:1020218608266

70. Singh D, Geat N, Rajawat MSV, Mahajan MM, Prasanna R, Singh $\mathrm{S}$, et al. Deciphering the mechanisms of endophyte-mediated biofortification of $\mathrm{Fe}$ and $\mathrm{Zn}$ in wheat. J Plant Growth Regul 2018;37:174-82; doi:10.1007/s00344-017-9716-4

71. Yadav AN, Singh J, Singh C, Yadav N. Current trends in microbial biotechnology for sustainable agriculture. Springer, Singapore, 2020.

72. Rastegari AA, Yadav AN, Yadav N. New and future developments in microbial biotechnology and bioengineering: trends of microbial biotechnology for sustainable agriculture and biomedicine systems: diversity and functional perspectives. Elsevier, Alpharetta, GA 2020 .

\section{How to cite this article:}

Rana KL, Kour D, Kaur T, Devi R, Yadav A, Yadav AN. Bioprospecting of endophytic bacteria from the Indian Himalayas and their role in plant growth promotion of maize (Zea mays L.). J Appl Biol Biotech 2021; 9(03): $41-50$. 